\title{
THE MASS MEDIA'S BEARING ON THE RESOLUTION OF POST-INDEPENDENCE SECURITY ISSUES IN NIGERIA
}

\author{
Osakue Stevenson Omoera ${ }^{1}$ \\ Adesina Lukuman Azeez ${ }^{2}$ \\ Roselyn Vona Doghudje ${ }^{3}$
}

\section{Introduction}

At the 1884-I885 Berlin Conference where African territories were divided among the European imperial powers, the disparate communities that were known to have been within the Niger Basin area of Africa came under the sphere of control and exploitation of the British (de Blij \& Muller 2003). Thus, the British colonialists formally and effectively occupied all the territories that are today known as Nigeria by claiming political hegemony over the peoples of the original separate nation-states, including the Yoruba Kingdom, Edo Kingdom, Hausa Kingdom, among other states to the west and south of Lake Chad. To ensure an effective rule, the British divided the various ethnic nationalities and kingdoms into southern and northern protectorates with different styles of rule and different goals or aspirations for the peoples in the two protectorates (Nnoli i978).

However, by I9I4, the British colonialists, through Lord Lugard (originally Frederick John Dealtry Lugard), created Nigeria by amalgamating the northern and southern protectorates, thereby, bringing together diverse peoples and regions into an artificial political entity with a little or no basis for commonality or nationality. Arguably, this lack of feeling of nationhood

\footnotetext{
I Department of Theatre and Media Arts, Ambrose Alli University, Ekpoma, Nigeria. Email: omoera@yahoo.com

2 Department of Mass Communication, University of Ilorin, Ilorin, Nigeria. Email: azeezogooluwa@yahoo.com

3 Department of Communication and Language Arts, University of Ibadan, Ibadan, Nigeria. Email: frukama2i@yahoo.com
} 
or the lack of national identity has endured and has been the bane of Nigeria's aspiration for progress and development. The lack of commitment to the Nigerian project, which the British foisted on the peoples that have continued to see themselves as markedly different from one another, has significantly shaped the history of Nigeria, inducing different crises and insurgencies that have threatened the its unity. Even after gaining independence from the British colonialists on October Ist, I960, the peoples of Nigeria could not see themselves as one and work together for the rapid socio-economic and socio-political of the country.

The umbrage and bitterness that welled up in the late ig6os led to the civil war of I967-1970, which almost tore Nigeria into splinters, but the agitations of the different peoples continue even till now, and a clear indication of this is the springing up of violent militias and terror groups among the ethnic or regional groups with furtive ideologies and political goals. Also implicated in this issue was the incursion of the military into governance for more than thirty years. Even though Nigeria has re-achieved civil rule since 1999, and has been managing the inchoate democracy for more than seventeen years, it continues to grapple with the issues of pettiness, animosity and struggle for the central political power among the different ethnic groups. All these have manifested in gargantuan crises and insurgencies, which incessantly put the unity and security of the country on tenterhooks. The overarching question that could be asked about this situation is: what have been the contributions of the mass media towards resolving or mitigating the security problems that have been plaguing and threatening the unity and corporate existence of Nigeria? This article seeks to provide an answer to this question.

\section{Objectives of the Study}

I. To assess the roles or contributions of the Nigerian mass media in mitigating or resolving the security challenges of insurgencies facing the country in the post-independence era (through the ways and manners they report the security issues).

2. To examine the basic strategies the Nigerian mass media have been adopting or could adopt to resolve or douse the security challenges that are threatening the unity and continuous existence of the country.

3. To determine the relationship between the media and the military or the security institutions that are charged with the responsibility of dousing or resolving security threats. 


\section{Research Questions}

I. What are the roles or contributions of the Nigerian mass media in mitigating or resolving the security challenges of insurgencies facing the country in the post-independence era (through the ways and manners they report the security issues)?

2. What are the basic strategies the Nigerian mass media have been adopting or could adopt to resolve or douse the security challenges that are threatening the unity and continuous existence of the country?

3. What is the relationship between the media and the military or the security institutions that are charged with the responsibility of dousing or resolving security threats?

\section{Theoretical Outlook}

Two major theories of mass communication explain and support the expected roles or contributions of the mass media in the resolution or attenuation of any form of threat to a nation's security. These are: the agenda setting and framing theories. Agenda setting theory refers to the idea that the emphasis that the mass media place on certain topics and the importance that people attribute to these topics are correlated (McCombs and Shaw i972). The concept of priming is often understood as an extension of agenda setting, as it describes the supposed effect that media reporting has on people's opinions regarding the issues in the public domain: "By making some issues more salient in people's mind (agenda setting), the mass media could also shape the considerations that people take into account when making judgments about political candidates or issues (priming)" (McCombs and Shaw I972). Relatively, "the mass media are significantly more than the only purveyor of information and opinion. They may not be successful much of the time in telling people what to think, but they are stunningly successful in telling their audience what to think about" (Cohen I963). This underscores why the mass media could influence the extent to which we hear and think about the incidences of security threats in the Nigerian nation.

Indeed, the media could influence perceptions on the security situations in a nation by dictating the way we know and think about the security threats. This is supported by the framing theory. Frames are patterns of interpretation offered by the media. Accordingly, the concept of framing consistently offers a way to describe the power of a communicating 
text (Entman I993; Iyengar I996). Framing is, therefore, based on the assumption that the way an issue is characterized in media reporting - positively, negatively or neutral - could influence people's perception regarding that particular issue. As Entman (I993) noted, "to frame is to select some aspects of a perceived reality and make them more salient in a communicating text, in such a way as to promote a particular problem definition, causal interpretation, moral evaluation, and/or treatment recommendation for the item described." Thus, the media could exaggerate; could escalate or mitigate; could raise panic and could soothe people's emotions by the way they report and describe security threats or attacks and their perpetrators.

\section{Methodology}

In assessing the real or actual contributions of the Nigeria media to the resolution or mitigation of the threats of post-independence challenges particularly that of Boko Haram insurgencies, to the Nigeria's national security, a triangulation of methods was adopted. Content analysis was adopted to analyze the reportage of the insurgencies in the Nigeria mass media with the aim of evaluating the impact of the news reports. The outcome of this constituted the basis for in-depth interviews (IDIs) with major stakeholders within Nigerian security institutions, who were purposively selected. Thus, 92 editions of two purposively selected Nigerian daily newspapers: The Punch and Daily Trust were analyzed. Forty six (46) editions each of these newspapers between Ist of September 2012 and 28th February 2013 formed the first sample of the study to measure the pattern of coverage of the Boko Haram insurgencies and any other security challenges that occurred during the period. Twenty military officers were also purposively selected for IDIs with the intention of examining their perceptions of the coverage of threats to national security by the Nigeria mass media. The IDIs were also aimed at establishing the nature of the relationship between the media and the military with the goal of determining whether or not the kind of relationship between the two institutions influences the extent to which the media have been contributing towards the resolutions of the security challenges facing the country.

\section{Understanding National Security: Some Perspectives}

Defining the concept of national security continues to be difficult because many factors underline its capacity at all levels of perception, and thus, cannot be restricted to a single definition due to its changing nature from 
one nation-state to another. Therefore, national security is a complex concept that is now being understood not only from the militarized perspective but also from a humanitarian perspective. Essentially, there are two major perspectives of understanding what national security stands for. The first perspective, commonly referred to as the Clausewitzian conceptualization of national security, is military-centred, statist, and parochial. It emphasizes the balance of power, balance of terror, containment, deterrence, flexible response and mutually assured destruction (Baylis \& Ranger 1992).

It is probably in the foregoing context that Luciani (I988; I990) conceived of national security as "the ability to withstand aggression from abroad." In other words, it is the ability of a nation-state to ward-off all forms of threat to its survival; the sustenance of its people as well as the ability of a state to protect its legitimate interests with all measures, including war. On this wisdom, national security is the decision-making process concerned with the identification of potential and actual threats, and the mobilization of resources in the frame that promptly ensures the safety and stability of the nation-state, while simultaneously, enhancing the promotion of national development, including the integrity of national territory and institutions (Luciani I990).

Fundamentally, the militarist/statist conceptualization of national security prides itself in the preservation of the nation-state: the territorial integrity and sovereignty and, therefore, focus on the roles of defence and security institutions (agencies). According to Lippmann quoted in Romm (I993), "a nation has security when it does not have to sacrifice its legitimate interests to avoid war, and is able, if challenged, to maintain them by war." In the same vein, Maier (I990) argues that "national security... is best defined as the capacity to control those domestic and foreign conditions that the public opinion of a given community believes is necessary to enjoy its own self-determination or autonomy, prosperity, and well-being".

The second perspective of understanding national security is known as the humanitarian perspective. It is a broader conceptualization of national security. According to Imobighe (I998), it (i.e., human security) emphasizes the security of individuals rather than the state. It entails the improvement in the lives of citizens in terms of freedom, education, healthcare, environmental protection, infrastructure and other amenities. It supports the protection of people from severe and pervasive threats and situations. The Commission on Human Security (2003) affirms further that it (i.e., human security) stresses on the creation of political, social, environmental, economic, military and cultural systems that together give people the building blocks of survival, livelihood and dignity. Drawing on this perspective, national security could be seen as the creation of conditions 
that contribute to a nation's political, social and economic consolidation and ensure its territorial integrity, its acquisition of capabilities to sustain these conditions, safeguard freedom of options and capabilities to survive in a volatile security environment.

It is the humanist conceptualization of national security that advocates for the improvement in the lives of citizens in terms of freedom, education, healthcare, environmental protection, infrastructure and other facilities. Thus, a threat to national security is an action or sequence of events that threatens drastically and over a brief time span to degrade the quality of life for the inhabitants of a state or threatens significantly to narrow the range of policy choices available to the government of a state or to private nongovernmental entities (Ullman quoted in Romm I993). The point here is that the conceptualization of national security remains dynamic, fluid and multi-directional, but it is considered critical to the survival of any nation-state. It embodies external security (safeguarding the nation from foreign threats), and internal security (within the state). It also highlights the maintenance of economic, military, political and diplomatic power over its peers and neighbouring countries (Imobighe I998). This means that national security cannot be linked or associated with national defence only; as it covers a wide range of aspects that require the cooperation and understanding of the state, its forces, institutions and the public. Therefore, national security in contemporary world means a situation where a nationstate or country seeks to incorporate human and societal security as a priority apart from national defence, thereby centring the fundamentals of security on the maintenance of peace and the eradication of conflict (Solomon 2007).

\section{Post-Independence Security Issues in the Nigerian State}

National security is a function of governance (part of the fundamental objectives and directive principles of the state, as it is entrenched in the 1999 Nigerian Constitution (as amended). Accordingly, it is the foundation of good governance, social welfare and economic development of a country and its people. Imobighe asserts that governance is the effective management of national affairs of a country at all levels of its functioning and execution, aimed at maintaining the integrity of the nation and the security of its people. To achieve good governance, it behoves the authorities to exercise political, economic and judicial procedures in a manner, which ensures that the people are given their freedom to fulfil their duties and resolve their disputes as it is allowed in the written constitution. That is a sure way to achieve good governance, but national security could be threatened when there is a high level of poverty, deprivation, and injustice in any nation-state. 
National security in the Nigerian state has been severally threatened since its independence by multidimensional issues. The challenges range from ethnic mistrust and bigotry, religious acrimonies, ethnic and border disputes to political hooliganism and violence as well as all forms of insurgencies against constituted authorities. These challenges threatened the oneness of the nation in the first republic to the extent that it led to the incursion of the military into governance; the military using the excuse of coming in to safeguard the integrity and continuous existence of the nation. However, in post- independence Nigeria, the real threats to its national security are no more limited to threats from other nation-states, but have been consistently built around internal crises and violence emanating from religious, ethnic and political acrimonies or differences. The most virulent of the challenges to Nigeria's national security is now terrorism as exemplified by a group of pseudo-Islamic extremists known as Boko Haram sects.

Kiras (2009) has conceptualized terrorism as the sustained use of violence against symbolic or civilian targets by small groups for political and social purposes, such as inspiring fear, drawing widespread attention to a political grievance, and/or provoking a draconian or unsustainable response. It aims at instilling fear among adversaries and intimidating third party persons who may or may not be direct targets. It may have a political, ideological or religious motivation or a combination of the three stratagems. As a consequence, terrorism becomes a calculated violence usually against symbolic targets, designed to deliver a political or religious message. Some of the goals of the terrorists include winning popular support, radicalising the populace, provoking the attacked people and government to act rashly; attracting recruits, polarizing the public opinion, demonstrating their ability to cause pain, or undermining governments (Onuoha 20I5).

Terrorists challenge the legitimacy of the political authority by resorting to fear, surprise, violence or threat of violence to achieve their goals through coercion, illegal and immoral use of force, transnational violence and internationalization of a conflict or demand along with the covert use or coverage by the media. It is a political violence against non-combatants or symbolic targets designed to communicate a message to the broader audience (Sinno 20II). The foregoing partly describes the operations of the Boko Haram sect(s) since it started its nefarious attacks on Nigeria in 2009; attacks that have resulted in the wanton destruction of lives and properties in parts of country, thereby threatening its national security (Omoera \& Ogah 20I6). 


\section{Mass Media and National Security: An Analysis of Relationship}

The emergence of Boko Haram as one of the toughest challenges to national security in Nigeria, with its vicious attacks on the populace, has demonstrated that the traditional threats to national security have metamorphosed into what cannot be contained by military forces or security institutions alone. The nature of the operations of Boko Haram sect(s) and many other insurgent groups in Nigeria, for instance, has shown that the Nigerian post-independence security problems require the collaboration of security organizations, which are state run such as the Nigerian army, the Nigerian police, the Department of State Security Service (DSS), etc., with non-state run bodies such as the media, the civilian joint task force (JTF), vigilantes, civil society groups, among others, whose combined efforts and expertises could help to mitigate, if not eradicate the terrorization of Nigeria. A robust combination of 'soft power', including intelligence reporting as represented by the mass media and 'hard power' as symbolized by the military or security institutions could be a very profitable joint effort that could help to douse the tense situations the terror groups have created in parts of the country.

This is in realization that the mass media are an important institution of any society (Uyo I987). Their value in contemporary society is underscored by the premium placed on them as the "fourth estate of the realm" (Akinfeleye 2003). As the fourth estate of the realm, the 1999 Nigerian Constitution (as amended) gives the Nigerian media statutory roles of monitoring the performance or responsibility of the government to the people. It holds that:

The press, radio, television, and other agencies of the mass media shall at all times be free to uphold the fundamental objectives contained in this chapter and uphold the responsibility and accountability of the government to the people (Federal Government of Nigeria 20II).

These statutory roles given to the Nigeria media are, of course, an integral part of the functions of the mass media as an important social institution. Such functions include: surveillance of the environment (watchman), correlation of parts of society in response to the environment (forum), transmission of cultural heritage from one generation to another (teacher) and entertainment (Lasswell (I948) and Wright (I958) quoted in Uyo I987). In analyzing the relationship between national security and the media, the function of the latter in respect of the surveillance of the environment requires further elucidation. By the surveillance of society, it 
is meant that "mass media watch over, guard and alert society of impending problems and often proffer the way forward (Odigbo 2003).

The point being made is that the media exercise surveillance over the environment and alert members of society to the realities of their environment. The media, more often than not, report what is wrong with/ in society and make concrete plans or create platforms to redress such inadequacies. In other words, surveillance of the environment means that the media provide information and alert their heterogeneous audience(s) of the changes that take place around them. In so doing, the media consistently survey the environment and convey salient issues or mediated messages to the audience in order to reduce uncertainties, thereby enabling people to react to conflicts or changes in a rational way. This is why they (the media) are commonly referred to as the fourth estate of the realm.

Given the tenacity and commitment with which the modern mass media have performed the foregoing roles, particularly that of the surveillance of society, in different parts of the world, the media have been generally considered as very powerful. It is an established fact that the mass media express and at the same time shape public opinion. They (re) construct images, perceptions and beliefs (Dahlgren 2007). Mass media educate people, correct misconceptions and give a better understanding of situations. As a mediator, the media provide outlets, offer solutions and build confidence. They are the main sources of most people's view of the world (Uyo 1987). Mass media are the most potent tools by means of which the masses ventilate their feelings and views on any issue of the day. Hence, the mass media could build public support regarding any government policy; they could effectively help to maintain contact and understanding between the government and the people; between rural areas and the cities; and among nation-states.

Nationally, the media are an important integrative agency. They are a powerful force as an educator, agitator, mobilizer, motivator, and entertainer. Their power could be great and immeasurable. They could create a feeling of involvement and participation. It is through them that the national agenda of the day is presented to the nation. They are a kind of national forum for the continuous debates on issues, which are a sine qua non for every society that seeks to improve on the living conditions of its people (Amoda I978). The point being made is that they set the agenda for national discourse. This explains why "the mass media force attention to certain issues. They build up public images of political figures. They are constantly presenting objects, which suggest what individuals in the mass should think about, know about, and have feelings about" (Lang and Lang quoted in McCombs and Shaw I972). 
The pertinent question at this juncture is: where do the media come into the resolution of the challenges of national security? Perhaps, the answer lies in the fact that the mass media are expected to work within the nationalistic and preventive frameworks in order to be able to check the threats on national security. There are various strategies for maintaining national security. Such strategies include the military approach; non-military approach; carrot and stick approach; development and governance approach; preventive diplomacy (intelligence gathering and sharing); and nationalistic approach. The nationalistic approach, in which the mass media have great roles to play, entails mass mobilization and it is information-driven. It is about intelligence gathering and intelligence sharing. It requires the media to set agenda for security policies and obtain public support for the security policies. It also requires the media to change people's perceptions about security issues through supportive framing. It entails propaganda against the vendors of insecurity, while engaging the whole nation with the government and the military in decision making and policy formulation regarding national security.

Thus, the mass media are expected to be used as a soft power in the processes or attempts at resolving the challenges of national security. Indeed, information (communication) as an instrument of soft power is increasingly becoming a strategic instrument within the context of a grand strategy because the media and the security sphere are dependent on one another, and security institutions, such as governments, depend on public support for their activities and opinion building (Copley I984). It is in this regard that we consider information purveyance as the fourth element of national power besides economic, military and diplomatic powers.

At any rate, soft power is the ability to obtain the outcome one seeks by attraction and persuasion rather than by coercion (Gilboa 2005). Power in contemporary times is the ability to change the behaviour of the nation-state and the people to be able to control the political environment through mediation. Power is becoming less coercive as military power has its limitations due to factors such as cost, time and place. Rather than using force to settle issues, to force perpetrators of dastardly acts to act in the manner one wants, soft power could be used to shape beliefs and preferences (Crelinsten 2005). Accordingly, for an efficient use of the concept of soft power, it is imperative for any nation-state to use information and communication technologies (ICTs) to deliver its message(s) and intent(s) to its own public, its neighbours and the world in general.

The media is an integral part of this soft power infrastructure, which could aid faster and more effective information dissemination, thereby helping a nation or its people interact and integrate at several levels. 
This is because soft power in today's world helps to build and manage perceptions in very significant ways. Thus, information, as an element of power disseminated through media, is a psychological dimension that could be effectively used for winning a war or resolving conflicts. To this end, the media could be used to generate political action aside from being an apparatus of national security. In this regard, the media could help to focus the attention of the public on a particular issue, and then help to frame and construct an understanding or perspective on the subject.

\section{Results and Analysis}

\section{Content analysis}

To assess or understand the contributions or roles of the Nigerian media in the resolution or mitigation of the security challenges threatening the continuous existence of the nation, the patterns and manners in which the media have been reporting the security challenges were analyzed as presented below:

Table 1: Framing of Boko Haram Insurgency Group(s) by the Nigerian Media

\begin{tabular}{|l|r|r|c|}
\hline Framing Categories & Daily Trust & The Punch & Total \\
\hline Terrorist Group & $19(46 \%)$ & $18(60 \%)$ & $37(53 \%)$ \\
\hline Ethnic Crusaders & $4(10 \%)$ & $3(10 \%)$ & $7(10 \%)$ \\
\hline Freedom Fighters & $3(7 \%)$ & - & $3(4 \%)$ \\
\hline Militant Groups & $2(5 \%)$ & - & $2(3 \%)$ \\
\hline Political Thugs & $9(22 \%)$ & $1(3 \%)$ & $10(14 \%)$ \\
\hline Islamic & $4(10 \%)$ & $8(27 \%)$ & $12(16 \%)$ \\
\hline Fundamentalists & $41(100 \%)$ & $30(100 \%)$ & $71(100 \%)$ \\
\hline Total & & &
\end{tabular}

Table I shows the frequency distribution of the framing categories by the selected newspapers.

Out of the 7I total news items reported by Daily Trust and The Punch, $37(53 \%)$ framed the Boko Haram sect as terrorist groups, 7(10\%) stories framed them as ethnic crusaders, $3(4 \%)$ framed them as freedom fighters, $2(3 \%)$ framed the sect as militant groups, Io (I4\%) framed them as political thugs and 12 (I6\%) framed Boko Haram sect(s) as Islamic fundamentalists. Specifically, out of $4 \mathrm{I}$ news items that the Daily Trust reported, I9 (46\%) 
framed Boko Haram sect(s) as terrorists groups, 4(10\%) as ethnic crusaders, $3(7 \%)$ as freedom fighters, $9(22 \%)$ framed the sect(s) as political thugs and 4 (I0\%) as Islamic fundamentalists. Also, out of 30 news items reported by The Punch, I8 (60\%) stories framed the sect(s) as terrorist groups, 3 (10\%) as ethnic crusaders, $\mathrm{I}(3 \%)$ framed Boko Haram as political thugs and 8 $(27 \%)$ as Islamic fundamentalists.

\section{Table 2: Causal Evaluation of Boko Haram Insurgencies by the Nigerian} Media

\begin{tabular}{|c|c|c|c|}
\hline Casual Evaluation & Daily Trust & The Punch & Total \\
\hline $\begin{array}{l}\text { Marginalisation of the } \\
\text { North }\end{array}$ & $12(28 \%)$ & $14(47 \%)$ & $26(38 \%)$ \\
\hline Stabilize the Country & $1(3 \%)$ & - & $1(1 \%)$ \\
\hline Islamise the Country & $5(12 \%)$ & $7(23 \%)$ & $12(18 \%)$ \\
\hline Initiate Disintegration & $23(57 \%)$ & $9(30 \%)$ & $32(43 \%)$ \\
\hline Total & $41(100 \%)$ & 30 (100\%) & 71 (100\%) \\
\hline
\end{tabular}

Table 2 shows the frequency distribution of framing categories in terms of causal evaluation. From 4I news items published by the Daily Trust, I2 (28\%) was caused to marginalize the north, I $3 \%$ ) to stabilize the country, 5(12\%) represented the causal evaluation to Islamise the country and $23(57 \%)$ to initiate disintegration. Also, from 30 news items published by The Punch, I4 (47\%) framed Boko Haram as aiming at marginalizing the north, $7(23 \%)$ to Islamise the country and $9(30 \%)$ to initiate disintegration. Overall, from a total of 7I news items published by Daily Trust and The Punch during the period under investigation, 26(38\%) was aimed at the marginalisation of the north, I (I\%) to stabilise the country, I2(I8\%) to Islamise the country and $32(43 \%)$ to initiate disintegration.

Table 3: Moral Evaluation of Boko Haram Sect(s) by the Nigerian Media

Moral Evaluation

Boko Haram Sect(s) are Devilish

Boko Haram Sect(s) are Dangerous

Boko Haram Sect(s) are Wicked

Boko Haram Sect(s) are Inconsiderate
Daily Trust

$1(2 \%)$

$8(20 \%)$

$9(22 \%)$

$15(37 \%)$
The Punch

Total

$3(10 \%) \quad 4(6 \%)$

$8(27 \%) \quad 16(23 \%)$

$8(27 \%) \quad 17(24 \%)$

$4(13 \%) \quad 19(25 \%)$ 


\section{Moral Evaluation}

Boko Haram Sect(s) are Ungodly

Total
Daily Trust
The Punch
Total
$8(19 \%)$
$7(23 \%)$
$15(21 \%)$
$41(100 \%)$
$30(100 \%)$

Table 3 shows the frequency distribution of the framing categories in terms of moral evaluation by the selected mass media outlets. Out of 4I news items published by the Daily Trust, I(2\%) see Boko Haram sect(s) as devilish, $8(20 \%)$ conceive Boko Haram sect(s) as dangerous, 9(22\%) consider them as wicked while $\mathrm{I} 5(37 \%)$ and 8 (I9\%) regard Boko Haram sect(s) to be inconsiderate and ungodly respectively. Out of the 30 news items published by The Punch during the period of under study, 3(10\%) consider the sect(s) to be devilish, $8(27 \%)$ consider them as dangerous, 8 $(27 \%)$ consider them as been wicked while $4(13 \%)$ news items frame them as inconsiderate and $7(23 \%)$ consider them as ungodly. Generally however, $4(6 \%)$ of the total editions of the two newspapers analysed established Boko Haram sect(s) as devilish, I6 (23\%) perceive them as dangerous, I7(24\%) consider them as wicked, while iو $(25 \%)$ regard them as inconsiderate and I5 (2I\%) established them as ungodly.

Table 4: Treatment Evaluation of Boko Haram Sect(s) by the Nigerian Media

\begin{tabular}{|c|c|c|c|}
\hline Treatment Evaluation & Daily Trust & The Punch & Total \\
\hline Given Amnesty & $17(42 \%)$ & $8(27 \%)$ & $25(35 \%)$ \\
\hline $\begin{array}{l}\text { Treated with Stick } \\
\text { and Instrument of } \\
\text { Government }\end{array}$ & $15(37 \%)$ & $20(66 \%)$ & $35(51 \%)$ \\
\hline Should be Ignored & $9(21 \%)$ & $2(7 \%)$ & $11(14 \%)$ \\
\hline Total & 41 (100\%) & 30 (100\%) & $71(100 \%)$ \\
\hline
\end{tabular}

Table 4 shows the frequency distribution of the framing categories in terms of treatment evaluation by the two selected newspapers. Out of the total 7I news items published by Daily Trust and The Punch, 25 (35\%) accounted that the Boko Haram sect(s) be given amnesty, 35 (52\%) said they should be treated with stick and instrument of government and II (I4\%) said the sect(s) should be ignored. Specifically, out of the 4I news items reported by the Daily Trust, I7 (42\%) said they should be given amnesty while I5 (37\%) said they should be treated with stick and instrument of government and $9(2 \mathrm{I} \%)$ said they should be ignored. Furthermore, out of the 30 news items reported by The Punch, $8(27 \%)$ said they should be given 
amnesty while 20 (66\%) said the Boko Haram sect(s) should be treated with stick and instrument of government and 2 (II\%) opined that they should be ignored.

Table 5: Direction of Stories on Boko Haram Conflicts by the Nigerian Media

Direction

Unfavourable

Favourable

Moderate

Total

\begin{tabular}{|r|r|c|}
\hline Daily Trust & The Punch & Total \\
\hline $37(90 \%)$ & $19(64 \%)$ & $56(77 \%)$ \\
\hline $1(3 \%)$ & $1(3 \%)$ & $2(3 \%)$ \\
\hline $3(7 \%)$ & $10(33 \%)$ & $13(20 \%)$ \\
\hline $41(100 \%)$ & $30(100 \%)$ & $71(100 \%)$ \\
\hline
\end{tabular}

Figure 1: Bar Chart Showing the Direction of Coverage by the Two Nigerian Newspapers

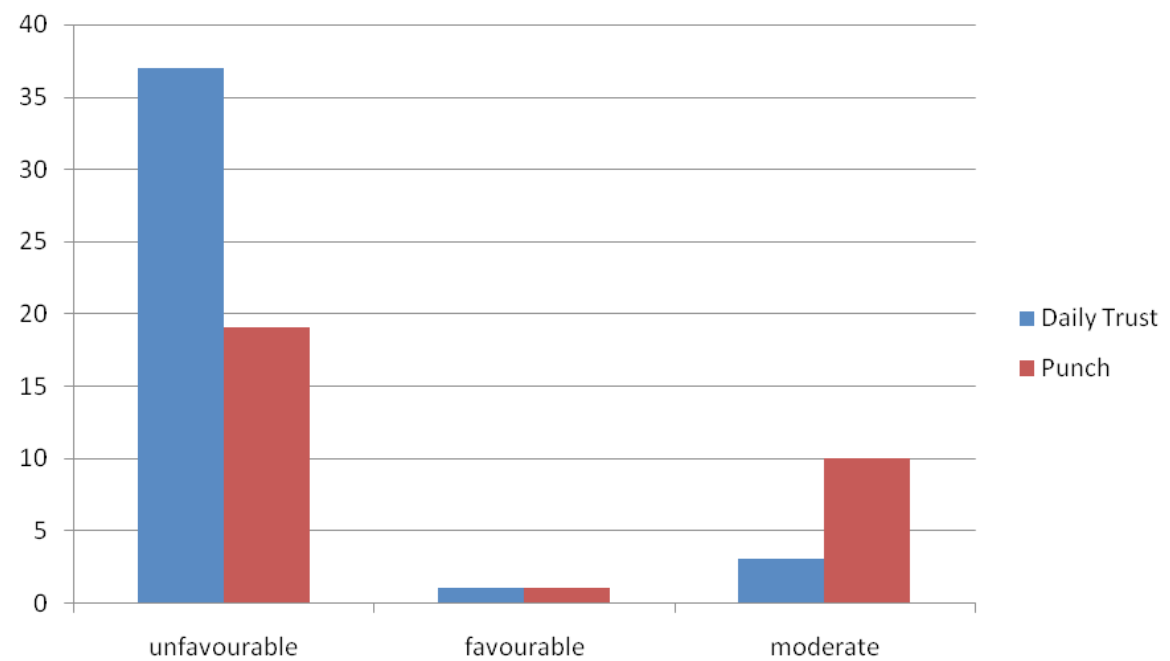

Table 5 and Figure I present the direction with which the coverage of Boko Haram conflicts were reported. Out of 7 I total news items, $56(77 \%)$ were unfavourable, meaning condemning Boko Haram action while 2 (3\%) were favourable, meaning supporting the acts and $13(20 \%)$ were moderate. Specifically, out of 4I news items that the Daily Trust reported during the period under investigation, 37 (90\%) condemned the acts (unfavourable), I $3 \%$ ) supported Boko Haram sect (s)' action (favourable) while $3(7 \%)$ neither condemned nor supported the acts (moderate). Out of the 30 news items published by The Punch to report Boko Haram sect(s)' activities, I9 (64\%) were unfavourable (condemned the Boko Haram sect(s)' action), I 
(3\%) were favourable (supported the action) and io (33\%) were moderate.

\section{In-depth Interviews}

On the effect of newspaper reportage of Boko Haram, the military personnel that were interviewed had the opinion that media reports on the security situation in Nigeria, particularly on Boko Haram has presented a reality of an unsafe society. A majority of them noted that media's reportage of the security situation in the country has exacerbated the situation rather than mitigate it because the reports have caused gratuitous panic among the Nigerian populace. They also argued that it has brought about self-fulfilling propensity that makes Boko Haram sect(s) to be more dangerous and violent, igniting similar or more violence that worsens the security situation in the country. Concerning the military's perception of the media, one of the military personnel interviewed captured the opinion of security institutions in a very insightful way:

The Nigeria media have an intrinsic propensity for sensationalism. They exhibit a Machiavellian urge to 'hit arses' by all cost. They have the tendency to exhibit a surprising naivety vis-à-vis the imperative of national security, and by induction [extension] the sovereignty of the state. The typical military is burdened with the following puzzle: "Is there an unspoken Fatwa to publish or perish, which somehow hangs over the head of the fourth realm of the state like the proverbial "swords of Damocles"?

Furthermore, the military personnel describe the media's perception of the military as follows:

The military displays a distinct proclivity for paranoid or schizophrenic behaviour and is mostly hostile. The military practices excessive caution with the media as a result of an unduly long memory of past travesties by the media. The in-built military practice of granting access to information on a need to know basis fails to take cognizance of the needs of the media. And this is the bane of the relationship between the two major institutions in the affairs of national security, and thus our national security suffers a major blow instead of being guaranteed.

The above two quotes represent the chief opinions of the military or security institutions about the media and their failure to support the military in mitigating all forms of security problems that have confronted the Nigerian state since independence. It captures the frosty relationship between the military and the media that have been hampering the efforts at 
resolving post-independence security challenges, which threaten the unity of the country. It captures the mistrust, misunderstanding and impatience that have characterized the relationship between the media and the military, and which, according to one of the military personnel who was interviewed, is age-long. He asserted that "much need to be done to disabuse the characteristics of the military in the past and the current realities on the ground about the military if the two (that is, the military and the media) must work together or assist each other in resolving the problem of insurgencies, which is threatening the peace of the Nigeria."

\section{Further Discussion and Conclusion}

The study revealed that the media are giving a wide coverage and attention to the security challenges of insurgencies and terrorism that have threatened/are still threatening the continued existence of Nigeria. That means they are performing their statutory roles of providing the needful information for the survival of individuals in the Nigerian state. This is in line with the observation of Hess \& Kalb (2003) who emphasized that the media should never be in the business of burying bad news, although some amount of decency and good judgment should be expected. The terrorists need attention, and the media cannot avoid giving them while they perform their statutory roles of informing the public. The media cover terrorism; they are likely to incite more terrorism, which produces more media coverage (Barnhurst I99rb). Hence, this complex situation tends to embolden or encourage terror groups, particularly Boko Haram sect(s) to perpetrate more nefarious activities.

Although most of the stories reported in the media, particularly in the Daily Trust and The Punch condemned Boko Haram sect(s)' attacks and threats, they (the news reports) negatively impacted on national security since the ways the media framed the attacks and their perpetrators tended to raise moral panic and make the terrorist sect(s) to appear more violent and invincible. A majority of the respondents in the IDIs agreed that newspapers' framing of Boko Haram sect(s)' activities escalates the security situation in Nigeria by making them more deviant. For instance, the military does not see the media as partnering meaningfully and honestly with them in making effort at resolving the threats of the post- independence security problems threatening the existence of Nigeria. There is appears to be a big mutual distrust between the media and the military, which has hampered and still hampering the cooperation of the two critical institutions in resolving the security challenges facing the nation. In view of the foregoing, the study posits that in spite of the robustness of the Nigerian media, they 
are yet to have a significant bearing on the elimination of security problems in post-independence Nigeria. Hence, the call for, among other things, a greater synergy between security institutions and mass media outfits in the country to achieve the deliverables.

\section{REFERENCES}

Akinfeleye, R.A. 2003. Fourth estate of the realm or fourth estate of the wreck: Imperative of social responsibility of the press. An inaugural lecture of the University of Lagos, Lagos. Lagos: University of Lagos.

Amoda, M. I978. Festac colloquium and Black world development: Evaluation of Festac colloquium agenda, Lagos programme i977. Lagos: Nigeria Magazine, Federal Ministry of Information.

Baylis, J \& Ranger, N.J. I992. Dilemmas of world politics. International issues in a changing world. Oxford: Clarendon Press.

Barnhurst, K.G. I991a. "The literature from terrorism”. In A.O. Alali and K. K. Eke (Eds.), Media coverage of terrorism, methods of diffusion (pp. II2-I37). London: Sage.

. I99Ib. "Contemporary terrorism in Peru: Sendero-Luminoso and the media". Journal of Communication, 4I(4), 75-89.

Cohen, B.C. I963. The press and foreign policy. Princeton, NJ: Princeton University Press.

Commission on Human Security. 2003. Human security now. New York: Commission on Human Security.

Copley G.R. I984. (Ed.). Defense and foreign affairs handbook. Virginia: Defense and Foreign Affairs Ltd.

Crelinsten, R. 2005. "Mass-mediated terrorism: The central role of the media in terrorism and counterterrorism". Political Communication, 22(I), II5-II8.

Dahlgren, P. 2007. Television and public sphere: Citizenship, democracy and the media. London: Sage.

de Blij, H. J. \& Muller, P.O. 2003. Geography: Realms, regions and concepts (IIth edition).Hoboken, NJ: Wiley.

Entman, R.M. 1993. "Framing: Toward clarification of a fractured paradigm". Journal of Communication, 43(4), 5I-59.

Federal Government of Nigeria. 20II. 1999 Nigerian constitution (as amended). Abuja: FGN.

Gilboa E. 2005. "The CNN effect: The search of a communication theory for 
international relations". Political Communication, 22, 27-44.

Hess, S. \& Kalb, M. 2003. (Eds.). The media and the war on terrorism (first edition). Washington, DC: Brookings Institution Press.

Imobighe, T.A. I998. The management of national security. An inaugural lecture of the Edo State University, Ekpoma, series Io. Ekpoma: Edo State University Publishing House.

Iyengar, S. I996. "Framing responsibility for political issues". Annals of the American Academy of Political and Social Science, 546, 59-70.

Kiras, J.D. 2009. "Irregular warfare: Terrorism and insurgency". Indian strategic knowledge online. Retrieved 25 Sept. 20I6, from http://www. indianstrategicknowledgeonline.com/web/baylis3e_cho9.pdf

Luciani, G. I988. “The economic content of security”. Journal of Public Policy, 8(2), I5I-I73.

. I990. "Allocation vs. production states: A theoretical framework". In H. Beblawi and G. Luciani (Eds.), The rentier state (pp.85-98). London: Routledge.

Maier, C. I990. Peace and security studies for the 1990s. Unpublished paper for MacArthur fellowship programme, social science research council.

McCombs, M. E. and Shaw, D.L. I972. "The agenda-setting function of mass media”. Public Opinion Quarterly, 36 (2), I76-I87.

Nnoli, O. I978. Ethnic politics in Nigeria. Enugu: Fourth Dimension Publishers.

Odigbo. 2003. "Role of public relations and the mass media in building and sustaining democracy”. In I. E. Nwosu (Ed.), Polimedia: Media and politics in Nigeria. Enugu: ACCE (Nigeria chapter).

Omoera, O.S. \& Ogah, C.A. 20I6. "Boko Haram as a-gent pro-vo-ca-teur of destruction and destabilization in Nigeria: The media's check". Brazilian Journal of African Studies, I(I), 67-84.

Onuoha, F. 20I5. From Boko Haram to Islamic State of West Africa Province (ISWAP): Radicalisation and recruitment in Nigeria. A paper presented in the countering violent extremism (CVE) media roundtable organised by the office of the national security adviser (ONSA) in collaboration with the European union technical assistance to Nigeria's evolving security challenges (EUTANS), Abuja, from 27th -28th October, 2015.

Romm, J.J. I993. Defining national security: The non-military aspect. New York: Council on Foreign Relations Press.

Sinno, A.H. 20II. "Armed groups' organizational structure and their strategic options". International Review of the Red Cross, 93(882), 3II-332. 
Solomon, H. 2007. “Introduction”. In H. Solomon (Ed.), Challenges to global security Geopolitical and power in the age of transition. London: I.B. Tauris Publishes.

Uyo, A.O. I987. Mass communication media: Classification and characteristics. New York: Civiletis International.

\section{ABSTRACT}

Conceptualising national security continues to be a taxing undertaking as a range of factors point up its capacity at all levels of perception, and thus, cannot be restricted to a single definition due to its changing nature from one nation-state to another. Therefore, national security remains dynamic, fluid and multi-directional, but it is critical to the survival of any nation-state. In post-independence Nigeria, security threats to its national interests not only involve conventional threats such as the ones from other nation-states but also non-state actors and activities such as terrorists, arms dealers, pirates, heists, drug traffickers, kidnappers, street gangster insurgencies, border disputes and ethnic militias. Over the past fifty six years or so, traditional threats to national security in Nigeria have metamorphosed into grave security behemoths, which apparently cannot be eliminated by military forces or security institutions alone. The mass media have been suggested to have the capacity to contribute meaningfully towards assisting security institutions in eliminating or checking the security challenges, which the country is confronted with. Perhaps, this is because the media are an integral part of the soft power infrastructure, which could facilitate the dissemination of information in a fast and effective way, thereby helping a nation such as Nigeria to put together the appropriate political action that is aimed at entrenching the desired national security. Deploying the agenda setting and framing theories, this article undertakes an appraisal of whether or not the Nigerian mass media (specifically, Daily Trust and The Punch) have made impactful contributions toward the resolution of security issues in post-independence Nigeria, with a particular reference to the Boko Haram sect(s)' insurgencies. It employs analytic, in-depth interviews (IDIs) and historical methods to look at some media reports on the insurgencies with the aim to evaluate their impact on the security of the Nigerian state. The study argued that in spite of the robustness of the Nigerian media, they are yet to have a significant bearing on the elimination of security problems in post-independence Nigeria. Hence, the call for, among other things, a greater synergy between security institutions and mass media outfits in the country to achieve the deliverables.

\section{KEYWORDS}

National security; Security institutions; Post-independence Nigeria; Media reportage; Soft power; Terrorism; Boko Haram; Security threats. 